\title{
The Role of High Density Lipoproteins in the Biodistribution of Two Radioiodinated Probes in the Rat
}

\author{
Raymond C. Pohland ${ }^{1}$ AND Raymond E. COUNSEll \\ Department of Pharmacology, University of Michigan Medical School, Ann Arbor, Michigan 48109-0010
}

Received April 12, 1984; accepted August 21, 1984

\begin{abstract}
The Role of High Density Lipoproteins in the Biodistribution of Two Radioiodinated Probes in the Rat. Pohland, R. C., AND Counsell, R. E. (1985). Toxicol. Appl. Pharmacol. 77, 4757. Two radioiodinated probes, ${ }^{125}$ I-cholesteryl oleate $\left({ }^{125} \mathrm{I}-\mathrm{CO}\right)$, a derivative of a natural constituent of lipoproteins, and 1-(2-chlorophenyl)-1-(4[ ${ }^{125}$ I]iodophenyl)-2,2-dichloroethane ( ${ }^{125} \mathrm{I}$-DDD), an analog of the adrenolytic drug $o, p^{\prime}$-DDD (mitotane), were selected to study the role of lipoproteins in drug disposition and to examine the ability of these vehicles to direct foreign molecules to specific tissues. In vivo and in vitro techniques were utilized to associate these probes with rat high density lipoproteins (HDL). Tissue distribution studies indicated that prior incorporation of ${ }^{125} \mathrm{I}-\mathrm{CO}$ into rat $\mathrm{HDL}$ increased the uptake of ${ }^{125} \mathrm{I}-\mathrm{CO}$ by rat adrenal, which was dramatically enhanced when this preparation was administered to animals made hypolipidemic with 4-aminopyrazolo-(3,4-d)-pyrimidine (4-APP). Acetylation of HDL labeled with ${ }^{125} \mathrm{I}-\mathrm{CO}$ provided evidence that the observed uptake into the adrenal was via a receptormediated process. In contrast with these results, prior association of ${ }^{125}$ I-DDD with rat HDI failed to alter the ability of this compound to accumulate in adrenal tissue of normal or hypolipidemic animals. Polyacrylamide gel electrophoresis (PAGE) was utilized to examine the stability of the association of ${ }^{125} \mathrm{I}-\mathrm{CO}$ and ${ }^{125} \mathrm{I}-\mathrm{DDD}$ with rat HDL. These results suggested that ${ }^{125} \mathrm{I}-\mathrm{CO}$ was associated with the lipophilic core of HDL, whereas ${ }^{125} \mathrm{I}-\mathrm{DDD}$ appeared to be partially associated with the suface components of HDL. Saturation of surface components with stable $o, p^{\prime}$-DDD offered data to suggest that this binding to apoproteins may disrupt the normal receptor-mediated uptake process. These studies indicate that lipoproteins may effect the distribution and tissue uptake of lipophilic compounds and, conversely, lipophilic molecules can effcet the metabolic fate of lipoproteins. The overall result is dependent upon the nature of the association of these lipophilic compounds with lipoproteins which is difficult to predict on the basis of molecular structure alone. (c) 1985 Academic Press, Inc.
\end{abstract}

Plasma lipoproteins consist of water-soluble complexes composed of a lipid core surrounded by surface phospholipids and apoproteins and are primarily responsible for transporting lipids such as triglycerides and cholesteryl esters to the various organs and tissues of the body. While extensive research has been performed dealing with serum albumin and its role in the transport of nu-

\footnotetext{
${ }^{1}$ Present address: Department of Biochemical Toxicology, Lilly Research Laboratories, P.O. Box 708, Greenfield, Ind. 46140.
}

merous endogenous and exogenous compounds (Kragh-Hansen, 1981), few studies have examined the role of plasma lipoproteins in the transport and delivery of foreign compounds. Nonetheless, the possible importance of lipoprotein binding or interaction with certain lipophilic compounds has been recognized. For example, recent studies have indicated that the interaction between lipoproteins and a variety of lipophilic compounds [i.e., insecticides (Skalsky and Guthrie, 1978; Maliwal and Guthrie, 1981), testosterone undecanoate (Hobbelen et al., 
1975), $\Delta^{9}$-tetrahydrocannabinol (Klausner et al., 1975), benzo[a]pyrene (Shu and Nichols, 1979, 1981; Busbee et al., 1982), polychlorinated biphenyls (Becker and Gamble, 1982), and chloroethylnitrosoureas (Weinkom et al., 1980)] involves partitioning of these lipophilic agents into the hydrophobic core of lipoproteins. Furthermore, Marinovich et al. (1983) have proposed that the binding of $2,3,7,8$ tetrachlorodibenzodioxin (TCDD) to plasma lipoproteins may actually delay the toxicity of this agent in experimental hyperlipidemia. It is these and similar observations that have lead to the possibility that plasma lipoproteins may play a significant role in the transport of nonpolar, lipophilic compounds.

The involvement of lipoproteins in pharmacokinetics becomes even more pertinent in light of recent findings (Brown and Goldstein, 1976; Brown et al., 1981) that indicate that these macromolecular complexes are taken up into specific cells by receptor-mediated processes. This process, first described in human fibroblasts, involves the binding of low density lipoproteins (LDL) to specialized membrane receptors. This specific binding to the receptor is transferred through the recognition apoproteins located on the surface of LDL. Once binding has occurred, the LDL-receptor complex is rapidly internalized by endocytosis. The importance of the various apoproteins in mediating the specific binding of lipoproteins has been demonstrated by chemically modifying the lysine residues of the lipoproteins by acetylation with diketene or acetic anhydride (Weisgraber et al., 1978). Such modification has been shown to abolish LDL binding and uptake via this specific receptor-mediated process.

According to currrent concepts, tissues responsible for the biosynthesis of steroid hormones derive their cholesterol from three possible sources, namely, (1) circulating plasma lipoproteins, (2) hydrolysis of intracellular cholesteryl esters, and (3) intracellular biosynthesis. In man, LDL are the major carrier of plasma cholesterol to extrahepatic tissues. However, studies with rats indicate that the adrenal cortex relies mainly upon circulating high density lipoproteins (HDL) as the source of cholesterol (Anderson and Dietschy, 1978; Carr et al., 1980; Faust et al., 1977; Balasubramaniam et al., 1977b). Once this source becomes depleted, as occurs upon treatment of rats with 4-aminopyrazolo[3,4-d]pyrimidine (4-APP), the adrenal gland increases the number of lipoprotein surface receptors, allowing increased uptake of the remaining circulating lipoproteins. Furthermore, intracellular cholesterol biosynthesis as well as hydrolysis of intracellular cholesteryl esters increases.

Utilizing the above information, this project was developed to study the role of lipoproteins in the transport and delivery of foreign molecules to the adrenal gland. Two radioiodinated tracers were selected for this study. One was a radioiodinated analog of mitotane $\left(o, p^{\prime}\right.$-DDD) a drug which markedly affects adrenal function and is used clinically to treat adrenal carcinoma, and the other was a radioiodinated analog of cholesteryl oleate, a normal constituent of the lipophilic core of lipoproteins (Fig. 1). Radioiodinated ${ }^{\left({ }^{125} I\right)}$ probes were selected on the basis of their ease of preparation and ease of detection in subsequent tissue analyses.

These radioiodinated compounds were
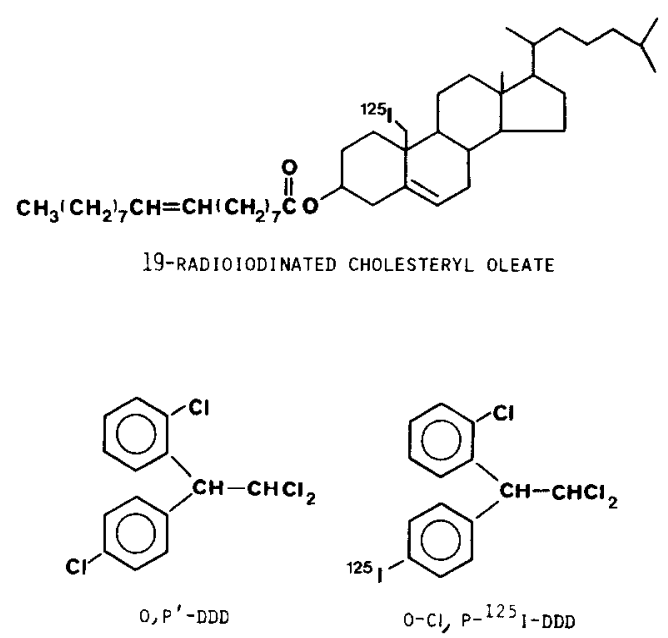

FIG. 1. Structures of ${ }^{125} \mathrm{I}-\mathrm{CO}$, unlabeled DDD, and ${ }^{125}$ I-DDD. 
utilized to study the role of lipoproteins in drug disposition, in general, and transport to the adrenal, specifically, by incorporating these probes into rat HDL prior to their administration to normal rats or to rats made hypolipidemic by treatment with 4-APP.

\section{METHODS}

Animals. Female Sprague-Dawley rats (Spartan Research Animals, Inc.) weighing 200 to $260 \mathrm{~g}$ were used in all experiments. The rats were housed in temperatureand light-controlled quarters and had free access to feed (Teklad 4\% rat and mouse diet) and water.

Radioiodinated DDD. 1-(2-Chlorophenyl)-1-(4-iodophenyl)-2,2-dichloroethane (I-DDD) was radioiodinated ( ${ }^{125}$ I-DDD) as described previously (Counsell et al., 1967), except for the use of the acetamide melt procedure (Seevers and Counsell, 1982) for the exchange reaction. Radiochemical purity was determined by thin-layer chromatography (TLC) using silica gel plates (Eastman Kodak) developed in hexane:1-butanol:acetic acid $(85: 5: 10 \mathrm{v} / \mathrm{v})$. Stable I-DDD standard was visualized by uv light, and the plate was scanned for radioactivity using a Berthold radiochromatogram scanner, Model LB2723. This analysis revealed a single radioactive peak coincident with the standard.

Radioiodinated cholesteryl oleate. [19-125I]Iodocholesteryl oleate $\left({ }^{125} \mathrm{I}-\mathrm{CO}\right)$ was prepared as previously described (Nordblom et al., 1980) and stored as an oil at $0^{\circ} \mathrm{C}$ until used. Radiochemical purity was determined by TLC as described above in the solvent system of benzene:ethyl acetate $(9: 1 \mathrm{v} / \mathrm{v})$. The plates were developed in iodine vapor and scanned for radioactivity as previously described. In all analyses, the single radioactive peak was coincident with the standard visualized with iodine vapor.

In vitro preparation of $H D L$ labeled with ${ }^{125} I-D D D$ $\left({ }^{125} I-D D D-H D L\right)$. Rat HDL were isolated from plasma according to the method of Havel et al. (1955). Very low density lipoproteins (VLDL) and LDL were first isolated in one fraction by adjusting the density of plasma to 1.070 with $\mathrm{KBr}$ and centrifuging for $20 \mathrm{hr}$ at $100,000 \mathrm{~g}$. HDL were then isolated by adjusting the density of the remaining solution to 1.210 with $\mathrm{KBr}$ and centrifuging for $45 \mathrm{hr}$ at $100,000 \mathrm{~g}$. The isolated $\mathrm{HDL}$ were then dialyzed overnight against 4 liters of $5 \mathrm{~mm}$ Tris buffer with $1 \mathrm{mM}$ EDTA at $\mathrm{pH} 7.4$, to remove the high concentration of salt. Purity of the isolated HDL was verified by polyacrylamide gel electrophoresis (PAGE) analysis (see below). Protein concentration of isolated HDL was determined following the modified Lowry procedure of Markwell et al. (1978).

${ }^{125}$ I-DDD was allowed to interact with HDL in a manner similar to that described by Shu and Nichols (1979). ${ }^{125} \mathrm{I}-\mathrm{DDD}(391.0 \mu \mathrm{Ci}, 2.58 \mu \mathrm{mol})$ previously immobilized on glass beads was incubated with a $4.5-\mathrm{ml}$ sample of $\mathrm{HDL}$ (19.8 mg protein) for $1 \mathrm{hr}$ at $37^{\circ} \mathrm{C}$. A subsequent experiment indicated that maximum uptake of compound from glass beads into HDL solution occurred at $1 \mathrm{hr}$ ( $74 \%$ uptake) when compared to a control solution of saline ( $<3 \%$ uptake).

After incubation, the radioiodinated HDL were then subjected to PAGE analysis and lipid extraction-TLC (see below) to assure the integrity of both the HDL and tracer.

In vivo preparation of $\mathrm{HDL}$ labeled with ${ }^{125} \mathrm{I}-\mathrm{CO}\left({ }^{125} \mathrm{I}\right.$ $\mathrm{CO}-\mathrm{HDL}$ ). Donor rats received iv injections of ${ }^{125} \mathrm{I}-\mathrm{CO}$ (1.2 to $1.4 \mathrm{mCi}, 2.30 \mu \mathrm{mol}$ ) via the tail vein in 2.0 to $2.5 \mathrm{ml}$ of vehicle (see below for formulation). At $0.5 \mathrm{hr}$ following injection, the rats were killed by exsanguination from the heart while under diethyl ether anesthesia. The blood was collected in heparinized Vacutainer tubes and centrifuged at low speed for $10 \mathrm{~min}$ to obtain plasma. Plasma from five rats was pooled (total volume, $9.0 \mathrm{ml}$ ), and the denisity was adjusted to 1.070 with $\mathrm{KBr}$ as described above. After ulracentrifugation at $100,000 \mathrm{~g}$ for $20 \mathrm{hr}$ at $15^{\circ} \mathrm{C}$, the top $2.0 \mathrm{ml}$ (containing CM, VLDL, and $\mathrm{LDL}$ ) was removed as previously described. The remaining infranate was used at ${ }^{125} \mathrm{I}-\mathrm{CO}-\mathrm{HDL}$. In a preliminary tissue distribution study, ${ }^{125} \mathrm{I}-\mathrm{CO}-\mathrm{HDL}$ obtained in this manner was compared to an HDL preparation that was further purified by ultracentrifugation as described above. Since there was no major difference in the tissue distribution profiles of these two preparations (results not shown), the second centrifugation step was omitted in subsequent preparations. This HDL preparation was then anaylyzed following the procedures described below.

Modification of HDL labeled with ${ }^{125} \mathrm{I}-\mathrm{CO}$. Chemical modification of the surface apoproteins of lipoproteins has been shown to prevent recognition by lipoprotein receptors (Weisgraber et al., 1978). To determine if the uptake of HDL labeled with ${ }^{125} \mathrm{I}-\mathrm{CO}$ into the adrenal was via a receptor-mediated process, HDL were modified with acetic anhydride following the procedure of Basu et al. (1976). Furthermore, by saturating the surface apoproteins with stable $o, p^{\prime}$-DDD, one might also observe a decrease in the adrenal uptake of ${ }^{125} \mathrm{I}-\mathrm{CO}-\mathrm{HDL}$.

Acetylated HDL were prepared by reacting the free amino groups of the lipoprotein with acetic anhydride, which increased the net negative charge of the lipoprotein particle. In a typical preparation, $80 \mu \mathrm{l}$ of a saturated solution of sodium acetate was added to $0.15 \mathrm{M} \mathrm{NaCl}$ $(0.5$ to $1.0 \mathrm{ml}$ ) containing 0.25 to $0.5 \mathrm{mg}$ HDL protein with continuous stirring in an ice-water bath. Next, acetic anhydride was added in multiple small aliquots $(0.2 \mu \mathrm{l})$ over a period of $1 \mathrm{hr}$ with continuous stirring. After the addition of a total mass of acetic anhydride equal to 1.5 times the mass of protein used, the mixture was stirred for an additional $30 \mathrm{~min}$. The reaction mixture was then dialyzed overnight at $4^{\circ} \mathrm{C}$ against 4 liters of buffer containing $5 \mathrm{~mm}$ Tris and $1 \mathrm{mM}$ EDTA at $\mathrm{pH} 7.4$. 
To demonstrate that the surface components of HDL could become saturated with stable $o, p^{\prime}$-DDD, unlabeled HDL were incubated with ${ }^{125}$ I-DDD and increasing amounts of stable $o, p^{\prime}$-DDD. ${ }^{125}$ I-DDD and stable $o, p^{\prime}-$ DDD (final mass $=0.01,0.1,0.2,0.5,1.0,2.0,5.0$, or $10.0 \mathrm{mg}$ ) were immobilized on glass beads in $5-\mathrm{ml}$ volumetric flasks as previously described. Each flask was then incubated with either $1.0 \mathrm{ml}$ of $\mathrm{HDL}(0.5 \mathrm{mg}$ protein) or $1.0 \mathrm{ml}$ of saline for $1 \mathrm{hr}$ at $37^{\circ} \mathrm{C}$. After incubation, triplicate counting aliquots wcre taken from each flask and the percentages of radioactivity released from the glass beads into either the HDL solution or the control saline solution was determined.

Formulation of ${ }^{125} I-D D D$ and ${ }^{125} I-C O$ for intravenous injection. Since ${ }^{125} \mathrm{I}-\mathrm{DDD}$ and ${ }^{125} \mathrm{I}-\mathrm{CO}$ are insoluble in aqucous solutions, these compounds were formulated in suspensions utilizing bovine serum albumin (BSA) and Tween-saline solutions, respectively. The biodistribution of ${ }^{125} \mathrm{I}$-DDD and ${ }^{125} \mathrm{I}-\mathrm{CO}$ administered in these standard preparations was then compared to their biodistribution when administered in association with lipoproteins.

${ }^{125}$ I-DDD was formulated for injection in a $2 \%$ BSA solution containing ethanol $(10 \% \mathrm{v} / \mathrm{v}) .{ }^{125} \mathrm{I}-\mathrm{CO}$ was formulated immediately prior to injection by the addition of Tween vehicle. This vehicle consisted of saline containing $10 \%$ ethanol and $1.6 \%$ Tween 80 (polyoxyethylenesorbitan monooleate, Sigma). Prior to injection, aliquots of the formulated compounds were assayed for radioactivity in a well counter. Aliquots were also analyzed by TLC as previously described.

Analysis of radioiodinated $H D L$. PAGE analysis of the HDL preparations was performed as described by Narayan (1975). Gels consisted of $3.5 \mathrm{~cm}$ of $3.75 \%$ (w/ v) main gel and $1.0 \mathrm{~cm}$ of $2.5 \%(w / v)$ large-pore stacking gel. A $50-\mu$ l aliquot of the fraction was mixed with 25 $\mu \mathrm{l}$ of Sudan black dye (a lipoprotein prestain) for $1 \mathrm{hr}$ and $25 \mu \mathrm{l}$ of the mixture was applied to the top of the stacking gel. The gels were run at $2.5 \mathrm{~mA} /$ tube until the leading band migrated $1.7 \mathrm{~cm}$ into the main gel. The gels were sliced into regions corresponding to lipoprotein bands as described by Narayan (1975): region 1, stacking gel CM; region 2, main gel VLDL/LDL; region 3, main gel HDL; region 4, main gel albumin; and region 5, main gel area below albumin. The regions were assayed for radioactivity in a well counter.

Additionally, to ascertain the stability of ${ }^{125}$ I-DDD and ${ }^{125} \mathrm{I}-\mathrm{CO}$ under the conditions of lipoprotein incorporation, $0.1-\mathrm{ml}$ aliquots of ${ }^{125} \mathrm{I}-\mathrm{DDD}-\mathrm{HDL}$ were mixed with $0.4 \mathrm{ml}$ distilled water and extracted with chloroform:methanol $(2: 1, \mathrm{v} / \mathrm{v})$ as described by Folch et al. (1957). The lipid extracts were then analyzed by TLC using the following systems to assess the percentage of radioactivity comigrating with the parent reference standard: ${ }^{125}$ I-DDD, hexane: 1-butanol:acetic acid (85:5:10 v/ v); ${ }^{125} \mathrm{I}-\mathrm{CO}$, benzene:ethyl acetate $(9: 1 \mathrm{v} / \mathrm{v})$.

Preparation of hypolipidemic rats. To determine the effect of lowering circulating plasma lipoprotein concentrations on the biodistribution of the radiolabeled HDL preparations, rats received a daily ip injection of a solution of 4-aminopyrazolo[3,4-d]pyrimidine (Sigma) in $10 \mathrm{~mm}$ sodium phosphate at $\mathrm{pH} 3.3$ (Shiff et al., 1971; Balasubramaniam et al., 1977a). The dose was 40 $\mathrm{mg} / \mathrm{kg}$ body weight per day for 3 days.

Tissue distribution of radioactivity after administration of ${ }^{125} I-D D D,{ }^{125} I-D D D-H D L,{ }^{125} I-C O$, or ${ }^{125} I-C O-H D L$ to normal and hypolipidemic rats. Groups of normal and 4-APP-treated rats each received $0.5 \mathrm{ml}$ of ${ }^{125} \mathrm{I}$ DDD, ${ }^{125} \mathrm{I}-\mathrm{DDD}-\mathrm{HDL},{ }^{125} \mathrm{I}-\mathrm{CO}$, or ${ }^{125} \mathrm{I}$-CO-HDL. The amount of radioactivity administered to each group was as follows: (1) ${ }^{125}$ I-DDD in $2 \%$ BSA vehicle, normal (12.1 $\mu \mathrm{Ci}, 0.27 \mu \mathrm{mol})$, 4-APP treated $(7.6 \mu \mathrm{Ci}, 0.15$ $\mu \mathrm{mol}) ;(2){ }^{125} \mathrm{I}-\mathrm{DDD}-\mathrm{HDL}$, normal $(6.6 \mu \mathrm{Ci})$, 4-APP treated $(6.6 \mu \mathrm{Ci}) ;(3){ }^{125} \mathrm{I}-\mathrm{CO}$ in Tween-saline vehicle, normal $(13.6 \mu \mathrm{Ci}, 0.18 \mu \mathrm{mol}), 4$-APP treated $(11.9 \mu \mathrm{Ci}$, $0.04 \mu \mathrm{mol}) ;(4){ }^{125} \mathrm{I}-\mathrm{CO}-\mathrm{HDL}$, normal $(7.5 \mu \mathrm{Ci}), 4-\mathrm{APP}$ treated $(0.9 \mu \mathrm{Ci})$. At least three animals were used in each group, and animals were killed at 5, 15, 30, and 60 min after injection by exsanguination from the heart. The blood was collected in heparinized Vacutainer tubes. Samples of whole blood were taken for counting, and the remaining blood centrifuged at low speed for $10 \mathrm{~min}$ to obtain plasma. The following organs were removed, rinsed of blood, and blotted dry: adrenal cortex, liver, ovaries, and thyroid. Large organs were minced with scissors. Samples were transferred to tared cellulose acetate capsules, weighed, and placed in polystyrene gamma tubes. Aliquots of plasma from all rats were analyzed by PAGE analysis as described above. Statistical analysis of the data were performed utilizing Student's $t$ test.

Measurement of in vitro transfer of radioiodinated probes from $\mathrm{HDL}$ following incubation with plasma components. To examine the stability of the association of ${ }^{125} \mathrm{I}-\mathrm{DDD}$ and ${ }^{125} \mathrm{I}-\mathrm{CO}$ with HDL, ${ }^{125} \mathrm{I}$-DDD-HDL and ${ }^{125} \mathrm{I}-\mathrm{CO}-\mathrm{HDL}$ were incubated with plasma. A 0.5 $\mathrm{ml}$ aliquot of ${ }^{125} \mathrm{I}$-DDD-HDL $(10.9 \mu \mathrm{Ci})$ was incubated with $6.0 \mathrm{ml}$ rat plasma at $37^{\circ} \mathrm{C}$ in a water bath with agitation. At 5, 15,30, and $60 \mathrm{~min}, 25-\mu$ l aliquots of the incubation medium were taken and analyzed by PAGE as previously described.

Since the ${ }^{125} \mathrm{I}-\mathrm{CO}-\mathrm{HDL}$ preparation contained all of the plasma components except the VLDL/LDL fraction which had previously been removed, ${ }^{125} \mathrm{I}-\mathrm{CO}-\mathrm{HDL}$ was incubated with rat lipoproteins of density $<1.070$ (VLDL + LDL). This incubation medium contained essentially the reconstituted components of rat plasma. Rat lipoproteins of density $<1.070$ were isolated as previously described. A $2.0-\mathrm{ml}$ aliquot of this fraction was incubated with $0.5 \mathrm{ml}$ of the ${ }^{125} \mathrm{I}-\mathrm{CO}-\mathrm{HDL}$ preparation as described above. At $0.5,1,3$, and $24 \mathrm{hr}, 25-\mu \mathrm{l}$ aliquots of the incubation medium were analyzed as mentioned above.

Tissue distribution of radioactivity after administration of modified HDL labeled with ${ }^{125} \mathrm{I}-\mathrm{CO}$ to normal and hypolipidemic rats. Groups of rats treated with 4-APP received $0.3 \mathrm{ml}$ of acetyl- ${ }^{125} \mathrm{I}-\mathrm{CO}-\mathrm{HDL}$ or DDD- ${ }^{125} \mathrm{I}-$ CO-HDL. Animals received either $2.0 \mu \mathrm{Ci}$ of acetyl- ${ }^{125} \mathrm{I}-$ 
CO-HDL or $1.6 \mu \mathrm{Ci}$ of DDD- ${ }^{125} \mathrm{I}-\mathrm{CO}-\mathrm{HDL}$. Three animals were used in each of the 4-APP-treated groups. Animals were killed at $15 \mathrm{~min}$ after injection by exsanguination from the heart. The tissue distribution of these modified HDL preparations was performed as described above. Statistical analysis of the data was performed utilizing Student's $t$ test.

\section{RESULTS}

Administration of ${ }^{125} \mathrm{I}-\mathrm{CO}$ to donor rats resulted in the appearance of approximately $5 \%$ of the dose in the HDL fraction within $0.5 \mathrm{hr}$. Ultracentrifugal separation gave an HDL fraction which upon gel electrophoresis showed the majority of radioactivity ( $>91 \%)$ to be associated with the HDL region. Moreover, lipid extraction of this HDL fraction and subsequent TLC analysis revealed that over $90 \%$ of the radioactivity remained associated with ${ }^{125} \mathrm{I}-\mathrm{CO}$.

The tissue distribution profile of ${ }^{125} \mathrm{I}-\mathrm{CO}$ and ${ }^{125} \mathrm{I}-\mathrm{CO}-\mathrm{HDL}$ is illustrated in Fig. 2. The uptake of radioactivity into the adrenal cortex significantly increased with both normal and hypolipidemic animals when HDL were labeled with ${ }^{125} \mathrm{I}-\mathrm{CO}$. In untreated animals there was a 4-fold increase in the adrenal uptake following administration of ${ }^{125} \mathrm{I}-\mathrm{CO}-$ HDL, as compared to ${ }^{125} \mathrm{I}-\mathrm{CO}$ in a Tweensaline vehicle. However, in 4-APP-treated animals, there was a 27 -fold increase in the adrenal uptake when ${ }^{125} \mathrm{I}-\mathrm{CO}-\mathrm{HDL}$ was compared to ${ }^{125} \mathrm{I}-\mathrm{CO}$.

Incubation of HDL with ${ }^{125}$ I-DDD previously immobilized on glass beads resulted in the transfer of $>77 \%$ of the initial radioactivity into the HDL phase. PAGE analysis of ${ }^{125}$ I-DDD-HDL showed that $>94 \%$ of the radioactivity migrated with the HDL band. Moreover, lipid extraction of ${ }^{125}$ I-DDD-HDL and subsequent TLC analysis revealed that over $95 \%$ of the radioactivity was still bound to the parent compound.

Figure 3 illustrates the tissue uptake of ${ }^{125}$ I-DDD and ${ }^{125}$ I-DDD-HDL at $15 \mathrm{~min}$ postinjection in normal and hypolipidemic rats. The highest percentage of radioactivity per gram of tissue was found in the adrenal

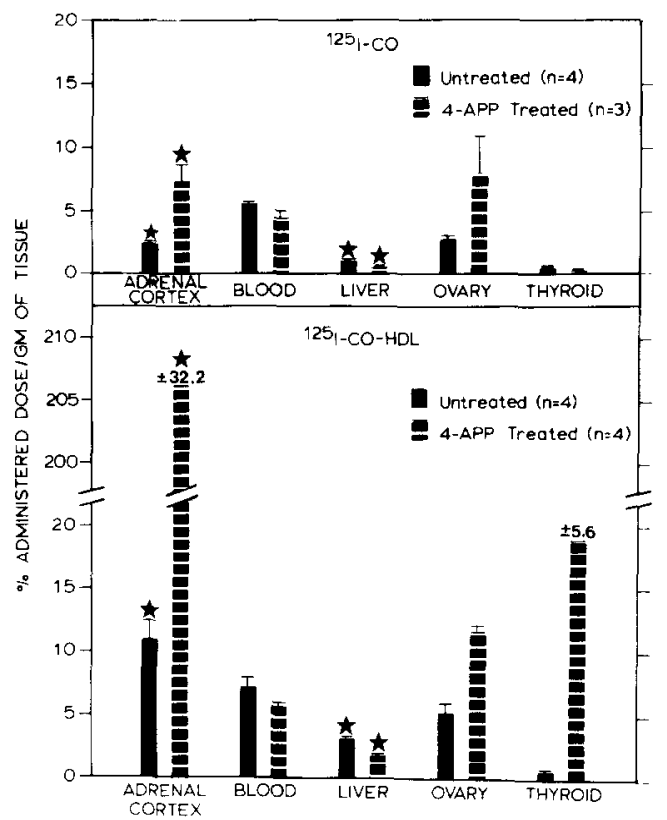

FIG. 2. Tissue uptake of ${ }^{125} \mathrm{I}-\mathrm{CO}$ and ${ }^{125} \mathrm{I}-\mathrm{CO}-\mathrm{HDL}$ at 15 min postinjection in normal and hypolipidemic rats. ${ }^{125} \mathrm{I}-\mathrm{CO}$ or ${ }^{125} \mathrm{~J}-\mathrm{CO}-\mathrm{HDL}$ was administered to either untreated or 4-APP-treated $(40 \mathrm{mg} / \mathrm{kg}$ body wt/day for 3 days, ip) rats. At $15 \mathrm{~min}$ postinjection, the rats were exsanguinated and the tissues removed, weighed, and analyzed for radioactivity. All values are expressed as the mean percentages of administered dose/g tissue $\pm \mathrm{SE}$. For comparison, the percentages of the administered dose/organ for adrenal cortex in untreated and 4-APP. treated rats following administration of ${ }^{125} \mathrm{I}-\mathrm{CO}-\mathrm{HDL}$ were $0.59 \pm 0.07$ and $10.71 \pm 1.65$, respectively. The liver values were $28.56 \pm 1.71$ and $16.10 \pm 0.70$, respectively. ${ }^{*} p<0.01$ for ${ }^{125} \mathrm{I}-\mathrm{CO}$ as compared to ${ }^{125} \mathrm{I}-$ CO-HDL for each tissue and treatment.

cortex at this time point in both untreated and 4-APP-treated animals. It was also noted that this time period coincided with the peak concentration of radioactivity in the adrenal cortex for both preparations in normal animals. However, in hypolipidemic animals, the peak concentration of radioactivity in the adrenal cortex for both preparations was 5 min postinjection and was similar to the value obtained at $15 \mathrm{~min}$ in normal animals (data not shown). Furthermore, there was no significant diffcrence in the tissue distribution for all tissues within treatment groups when ${ }^{125}$ I-DDD was administered associated with HDL or in a $2 \%$ BSA vehicle (Fig. 3 ). 


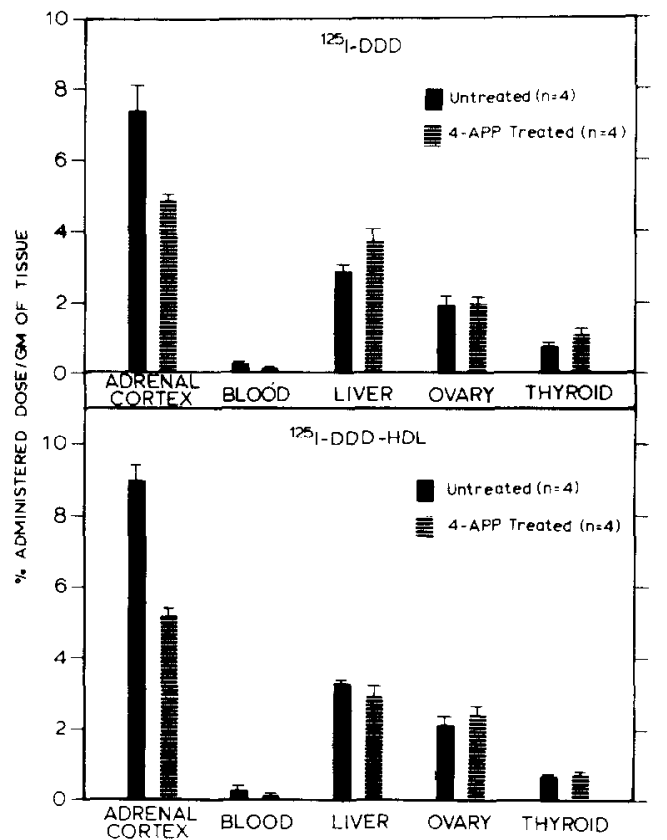

Fig. 3. Tissue uptake of ${ }^{125}$ I-DDD and ${ }^{125}$ I-DDDHDL at 15 min postinjection in normal and hypolipidemic rats. ${ }^{125}$ I-DDD or ${ }^{125}$ I-DDD-HDL was intravenously administered to either untreated or 4-APP-treated adult female Sprague-Dawley rats. Tissue distribution was performed as described in Fig. 2.

Since the adrenal uptake of ${ }^{125} \mathrm{I}-\mathrm{CO}-\mathrm{HDL}$ was dramatically greater than that observed for ${ }^{125}$ I-DDD-HDL, the stability of the association of ${ }^{125} \mathrm{I}-\mathrm{CO}$ and ${ }^{125} \mathrm{I}-\mathrm{DDD}$ with HDL was examined in vivo and in vitro. PAGE analysis of ${ }^{125} \mathrm{I}-\mathrm{CO}-\mathrm{HDL}$ prior to adminis- tration to normal rats indicated that $88 \%$ of the radioactivity was located in the HDL region (Table 1). Following in vivo administration of ${ }^{125} \mathrm{I}-\mathrm{CO}-\mathrm{HDL}$, a majority of the radioactivity remained with the HDL region even after $24 \mathrm{hr}$ postinjection. Similar results were obtained following in vitro incubation of ${ }^{125} \mathrm{I}-\mathrm{CO}-\mathrm{HDL}$ with a plasma fraction of $d$ $<1.070$ (i.e., reconstituted plasma). These data support the view that ${ }^{125} \mathrm{I}-\mathrm{CO}$ is tightly associated with HDL and is in all probability confined to the lipid core in a manner similar to that proposed for other cholesteryl esters.

PAGE analysis of ${ }^{125} \mathrm{I}$-DDD-HDL prior to administration to normal rats indicated that $>94 \%$ of the radioactivity was located in the HDL region (Table 2). However, following in vivo administration of ${ }^{125} \mathrm{I}-\mathrm{DDD}$ HDL, there was a rapid redistribution of radioactivity from HDL to other plasma components. Similarly, in vitro incubation of ${ }^{125}$ I-DDD-HDL with whole rat plasma caused a rapid redistribution of radioactivity to other regions of the gel. These findings suggest that a portion of ${ }^{125}$ I-DDD is associated with the surface components of HDL (i.e., apoproteins). This could account for the observed rapid exchange of ${ }^{125}$ I-DDD from HDL to other plasma components.

To confirm the participation of ${ }^{125} \mathrm{I}-\mathrm{CO}-$ HDL in receptor-mediated uptake by the adrenal, this preparation was acetylated with

TABLE 1

In Vivo and in Vitro AsSOCIaTION of ${ }^{125} \mathrm{I}-\mathrm{CO}$ with Plasma COMPONENTS as Determined by PaGE

\begin{tabular}{|c|c|c|c|c|c|}
\hline \multirow[b]{2}{*}{ Gel region } & \multirow[b]{2}{*}{$0 \mathrm{hr}$} & \multicolumn{2}{|c|}{$\begin{array}{l}\text { After in vivo } \\
\text { administration of }{ }^{125} \mathrm{I}- \\
\text { CO-HDL }\end{array}$} & \multicolumn{2}{|c|}{$\begin{array}{l}\text { After in vitro incubation of } \\
{ }^{125} \mathrm{I}-\mathrm{CO}-\mathrm{HDL} \text { with a plasma } \\
\text { fraction of } d<1.070\end{array}$} \\
\hline & & $0.5 \mathrm{hr}$ & $24 \mathrm{hr}$ & $0.5 \mathrm{hr}$ & $24 \mathrm{hr}$ \\
\hline CM/VLDL & $4.2^{a}$ & $0.3 \pm 0.1^{h}$ & 26.4 & $7.0 \pm 1.5$ & $4.6 \pm 0.8$ \\
\hline LDL & 2.6 & $3.9 \pm 0.8$ & 6.0 & $5.0 \pm 0.2$ & $5.4 \pm 0.5$ \\
\hline HDL & 88.0 & $87.4 \pm 1.0$ & 60.1 & $82.2 \pm 0.2$ & $87.8 \pm 0.4$ \\
\hline Albumin & 3.6 & $3.0 \pm 0.1$ & 3.1 & $1.0 \pm 0.4$ & $0.5 \pm 0.0$ \\
\hline Below albumin & 1.5 & $5.4 \pm 0.1$ & 4.3 & $4.7 \pm 0.6$ & $1.6 \pm 0.1$ \\
\hline
\end{tabular}

${ }^{a}$ Data are expressed as percentages of total radioactivity in each region.

${ }^{b} \bar{x} \pm \mathrm{SE}$. 
TABLE 2

In Vivo and in Vitro Association of ${ }^{125}$ I-DDD with Plasma COMPONENTS as Determined by PAGE

\begin{tabular}{|c|c|c|c|c|c|}
\hline \multirow[b]{2}{*}{ Gel region } & \multirow[b]{2}{*}{$0 \mathrm{~min}$} & \multicolumn{2}{|c|}{$\begin{array}{l}\text { After in vivo administration of } \\
{ }_{125} \text { I-DDD-HDL }\end{array}$} & \multicolumn{2}{|c|}{$\begin{array}{l}\text { After in vitro } \\
\text { incubation of }{ }^{125} \mathrm{I}- \\
\text { DDD-HDL with } \\
\text { whole plasma }\end{array}$} \\
\hline & & $5 \mathrm{~min}$ & $30 \mathrm{~min}$ & $5 \mathrm{~min}$ & $30 \mathrm{~min}$ \\
\hline CM/VLDL & $1.3^{a}$ & $21.2 \pm 1.9^{b}$ & $12.0 \pm 1.6$ & 34.1 & 32.3 \\
\hline LDL & 2.7 & $11.6 \pm 1.6$ & $7.4 \pm 0.4$ & 16.0 & 18.1 \\
\hline HDL & 94.7 & $25.8 \pm 2.8$ & $27.0 \pm 4.3$ & 29.0 & 30.1 \\
\hline Albumin & 1.1 & $40.6 \pm 4.7$ & $53.4 \pm 3.0$ & 20.7 & 19.3 \\
\hline Below albumin & 0.2 & $0.7 \pm 0.3$ & $0.2 \pm 0.2$ & 0.1 & 0.1 \\
\hline
\end{tabular}

${ }^{a}$ Data are expressed as percentages of total radioactivity in each region.

${ }^{b} \bar{x} \pm \mathrm{SF}$.

acetic anhydride and administered to 4-APPtreated rats. This chemical modification of the surface apoproteins of HDL prevents recognition by lipoprotein receptors (Weisgraber et al., 1978).

As indicated in Fig. 4, when ${ }^{125} \mathrm{I}$-DDD $(0.01 \mathrm{mg})$ was incubated without additional stable $o, p^{\prime}$-DDD, approximately $90 \%$ of the radioactivity was released from the glass beads

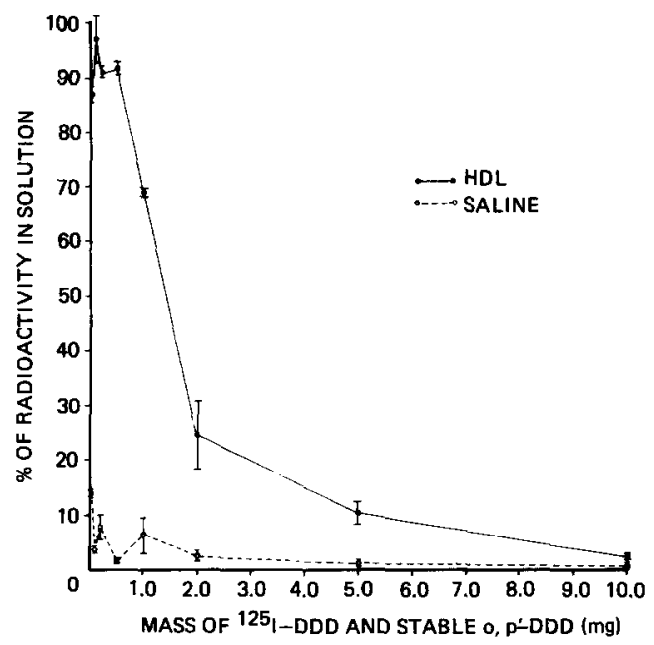

FIG. 4. Incubation of ${ }^{125} \mathrm{I}$-DDD with increasing amounts of stable $o, p^{\prime}$-DDD. To demonstrate that the surface components of HDL could become saturated with stable $o, p^{\prime}$-DDD, unlabeled HDL were incubated with ${ }^{125} \mathrm{I}$ DDD and increasing amounts of stable $o, p^{\prime}$-DDD. See text for details. into the HDL solution as compared to only approximately $10 \%$ of the radioactivity becoming soluble in saline. PAGE analysis of the HDL solution also inidicated that $>70 \%$ of the radioactivity in solution was associated with the HDL component. Furthermore, as increasing amounts of stable $o, p^{\prime}$-DDD were added to ${ }^{125}$ I-DDD, less radioactivity became associated with HDL. As indicated in Fig. 4, HDL became completely saturated as the mass of stable $o, p^{\prime}$-DDD approached $10 \mathrm{mg}$. At all concentrations of $o, p^{\prime}-\mathrm{DDD},<10 \%$ of the radioactivity was released into the saline solution.

These results therefore indicate that 0.5 mg of HDL protein can become completely saturated with $o, p^{\prime}$-DDD when incubated with $10 \mathrm{mg}$ of this compound. As a result, HDL labeled with ${ }^{125} \mathrm{I}-\mathrm{CO}(0.25 \mathrm{mg}$ protein) were incubated with $10 \mathrm{mg}$ stable $o, p^{\prime}$-DDD previously immobilized on glass beads as described under Methods.

Figure 5 illustrates the tissue uptake of ${ }^{125} \mathrm{I}-\mathrm{CO}-\mathrm{HDL}$, acetyl- ${ }^{125} \mathrm{I}-\mathrm{CO}-\mathrm{HDL}$, and DDD- ${ }^{125} \mathrm{I}-\mathrm{CO}-\mathrm{HDL}$ at $15 \mathrm{~min}$ postinjection in hypolipidemic rats. Acetylation significantly decreased the uptake of ${ }^{125}$ I-CO-HDL into steroid-secreting tissues of hypolipidemic rats. Furthermore, saturation of ${ }^{125} \mathrm{I}-\mathrm{CO}-\mathrm{HDL}$ with $o, p^{\prime}$-DDD (DDD- ${ }^{125} \mathrm{I}-\mathrm{CO}-\mathrm{HDL}$ ) appeared to slightly perturb the uptake of ra- 


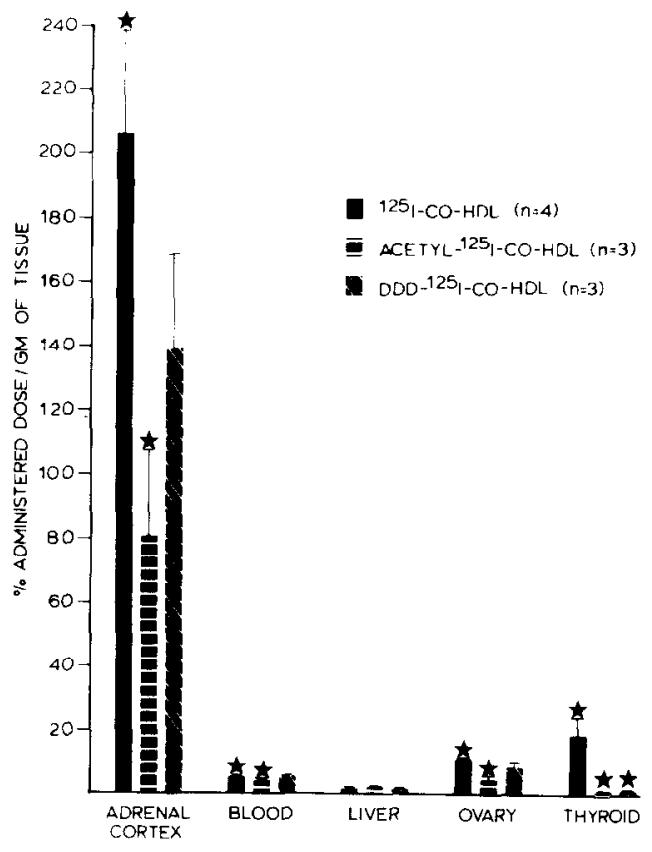

FIG. 5. Tissue uptake of ${ }^{125} \mathrm{I}-\mathrm{CO}-\mathrm{DDD}$, acetyl- ${ }^{125} \mathrm{I}-$ $\mathrm{CO}-\mathrm{HDL}$, and DDD-125 I-CO-HDL at $15 \mathrm{~min}$ postinjection in hypolipidemic rats. ${ }^{125} \mathrm{I}-\mathrm{CO}-\mathrm{HDL}$, acetyl- ${ }^{125} \mathrm{I}-$ CO-HDL, or DDD- ${ }^{125} \mathrm{I}-\mathrm{CO}-\mathrm{HDL}$ was administered as in Fig. 2. ${ }^{*} p<0.05$ for ${ }^{125} \mathrm{I}-\mathrm{CO}-\mathrm{HDL}$ as compared to acetyl- ${ }^{125}$ I-CO-HDL for each tissue.

dioactivity into these same tissues. However, on a statistical basis the tissue uptake of DDD- ${ }^{125} \mathrm{I}-\mathrm{CO}-\mathrm{HDL}$ was not significantly different from that of ${ }^{125} \mathrm{I}-\mathrm{CO}-\mathrm{HDL}$. The observation that saturating ${ }^{125} \mathrm{I}-\mathrm{CO}-\mathrm{HDL}$ with $o, p^{\prime}$-DDD only slightly altered adrenal uptake is consistent with the rapid redistribution of ${ }^{125}$ I-DDD from HDL to other plasma components. This rapid loss of $o, p^{\prime}$-DDD from the surface of ${ }^{125} \mathrm{I}-\mathrm{CO}-\mathrm{HDL}$ could account for the greater adrenal uptake of radioactivity from DDD- ${ }^{125} \mathrm{I}-\mathrm{CO}-\mathrm{HDL}$ than observed for acetyl- ${ }^{125} \mathrm{I}-\mathrm{CO}-\mathrm{HDL}$.

\section{DISCUSSION}

When ${ }^{125} \mathrm{I}-\mathrm{CO}-\mathrm{HDL}$ was administered to normal rats, its specific activity was immmediately reduced by the endogenous plasma lipoproteins. This, in turn, could explain the modest increase of uptake of radioactivity by the adrenal when ${ }^{125} \mathrm{I}-\mathrm{CO}-\mathrm{HDL}$ was administered to normal animals. Treatment of rats with 4-APP, however, caused a profound lowering of circulating lipoprotein concentrations, thus minimizing dilution of ${ }^{125} \mathrm{I}-\mathrm{CO}-$ HDL upon administration. Moreover, this decrease in circulating lipoproteins could also cause an increase in the number of HDL receptors in target tissues, which is consistent with the known regulation of adrenal activity (Brown et al., 1981; Balasubramaniam et al., 1977b; Pittman et al., 1982). Both or either one of these possibilities could account for the dramatic increase in adrenal uptake of ${ }^{125} \mathrm{I}-\mathrm{CO}-\mathrm{HDL}$ in the hypolipidemic animals.

On the basis of these studies, it appears that the association of these lipophilic compounds with HDL depends upon their molecular properties. It is proposed that ${ }^{125} \mathrm{I}-\mathrm{CO}$ becomes incorporated in to the lipophilic core of HDL and that the resulting ${ }^{125} \mathrm{I}-\mathrm{CO}$-labeled HDL are capable of participating in the normal receptor-mediated uptake process characteristic of the adrenal. On the other hand, the results of this study suggest that ${ }^{125}$ I-DDD associates with the surface as well as the core components of HDL. Such binding of drugs to the surface apoproteins could perturb the normal receptor-mediated uptake process.

In a preliminary experiment, the electrophoretic migration of unlabeled HDL treated with only sodium acetate was compared to HDL treated with both sodium acetate and acetic anhydride. As seen in Fig. 6, PAGE analysis indicated that treatment of $\mathrm{HDL}$ with sodium acetate alone did not alter the gel migration pattern when compared to that of untreated control HDL. On the other hand, treatment of HDL with sodium acetate and acetic anhydride resulted in an altered gel migration pattern. The acetylated HDL appeared to migrate more rapidly toward the cathode, which is consistent with results obtained by Basu et al. (1976). HDL labeled with ${ }^{125} \mathrm{I}-\mathrm{CO}$ were then acetylated with acetic 


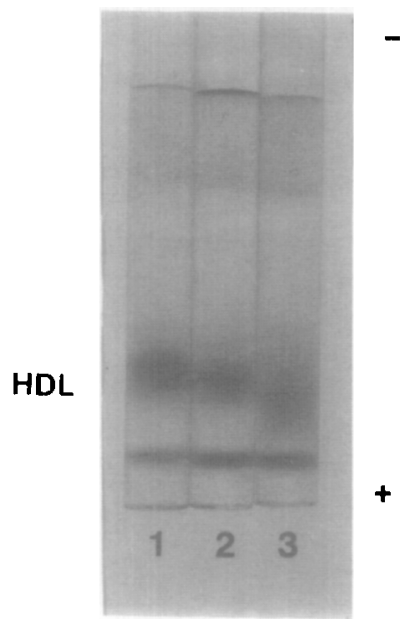

FIG. 6. PAGE analysis of acetylated HDL was performed on (1) untreated rat HDL, (2) rat HDL treated with sodium acetate, and (3) rat HDL treated with sodium acetate and acetic anhydride.

anhydride (acetyl $-{ }^{125} \mathrm{I}-\mathrm{CO}-\mathrm{HDL}$ ) and the tissue distribution of these modified HDL was compared to the tissue distribution of ${ }^{125} \mathrm{I}$ CO-HDL. PAGE analysis of ${ }^{125} \mathrm{I}-\mathrm{CO}-\mathrm{HDL}$ incubated with acetic anhydride indicated that the acetylated ${ }^{125} \mathrm{I}$-CO-HDL (acetyl $-{ }^{125} \mathrm{I}-$ CO-HDL) migrated more rapidly toward the cathode. Furthermore, when the gel was sliced and counted, the majority of the radioactivity was found associated with the more rapidly migrating band.

As previously indicated, results from PAGE anaylsis indicated that a significant amount of ${ }^{125}$ I-DDD was interacting with the surface components of HDL. ${ }^{125}$ I-DDD could be binding to the surface apoproteins of HDL which are responsible for receptor recognition. Therefore, by completely saturating the surface apoproteins with stable $o, p^{\prime}-\mathrm{DDD}$, one might observe a decrease in the adrenal uptake of ${ }^{125} \mathrm{I}$-CO-labeled HDL.

The dramatic uptake of ${ }^{125} \mathrm{I}-\mathrm{CO}-\mathrm{HDL}$ into the adrenal and, to a lesser extent, the ovaries is consistent with the results obtained in vitro and in vivo (Andersen and Dietschy, 1978; Balasubramaniam et al., 1977b, 1976; Gwynne and Hess, 1978; Strauss et al., 1982) for the receptor-mediated uptake of lipoproteins into sterioid-secreting tissues in the rat. Furthermore, these results suggest $o, p^{\prime}$-DDD may be partially interfering with receptormediated uptake by binding to surface apoproteins of HDL. In this regard, it is noteworthy that adrenal imaging with radioiodinated cholesterol analogs is oftentimes unsuccessful with patients undergoing treatment with $o, p^{\prime}$-DDD (Gross et al., 1981).

In conclusion, this study has shown that lipophilic compounds become associated with lipoproteins and that the nature of this association depends upon molecular properties that are not readily apparent. Lipophilic compounds may become incorporated into the lipophilic core of lipoproteins and/or bind to their surface components. Moreover, compounds which become incorporated into the core of lipoproteins may participate in receptor-mediated uptake into tissues such as the adrenal and thereby accumulate in such tissues. On the other hand, drugs that bind to the surface apoproteins of lipoproteins may interfere with the normal receptor-mediated processes and thereby alter the metabolic fate of plasma lipoproteins. On the basis of this study, the effect of lipoproteins on drug disposition and transport as well as the effect of drugs on lipoprotein metabolism deserves further examination.

\section{ACKNOWLEDGMENTS}

The authors acknowledge Jamey Weichert for radiolabeling the compounds utilized in this research and Susan Schwendner for her efforts in the tissue distribution phase of this study. This reseach was supported by Grant CA-08349 awarded by the National Cancer Institute; USPHS, NIH Grant T32-GM07767; and a Horace H. Rackham Predoctoral Fellowship and Dissertation Grant.

\section{REFERENCES}

ANDERSEN, J. M., AND DIETSChY, J. M. (1978). Relative importance of high and low density lipoproteins in the regulation of cholesterol synthesis in the adrenal 
gland, ovary, and testis of the rat. J. Biol. Chem. 258, 9024-9032.

Balasubramaniam, S., Goldstein, J. L., and Brown, M. S. (1977a). Regulation of cholesterol synthesis in rat adrenal gland through coordinate control of 3hydroxy-3-methylglutaryl coenzyme A synthase and reductase activities. Proc. Natl. Acad. Sci. USA 74, 1421-1425.

Balasubramaniam, S., Goldstein, J. L., Faust, J. R., AND BROWN, M. S. (1976). Evidence for regulation of 3-hydroxy-3-methylglutaryl coenzyme $A$ reductase activity and cholesterol synthesis in nonhepatic tissues of rat. Proc. Natl. Acad. Sci. USA 73, 2564 2568.

Balasubramaniam, S., Goldstein, J. L., Faust, J. R., Brunschede, G. Y., AND Brown, M. S. (1977b). Lipoprotein-mediated regulation of 3-hydroxy3-methylglutaryl coenzyme A reductase activity and cholesteryl ester metabolism in the adrenal gland of the rat. J. Biol. Chem. 252, 1771-1779.

Basu, S. K., Goldstein, J. L., Anderson, R. G. W., AND BROWN, M. S. (1976). Degradation of cationized low density lipoprotein and regulation of cholesterol metabolism in homozygous familial hypercholesterolemia fibroblasts. Proc. Natl. Acad. Sci. USA 73, 31783182.

BECKER, M. M., AND GAMBLE, W. (1982). Determination of the binding of $2,4,5,2^{\prime}, 4^{\prime}, 5^{\prime}$-hexachlorobiphenyl by low density lipoprotein and bovine serum albumin. $J$. Toxicol. Environ. Health 9, 225-234.

BRown, M. S., AND GoldsteIN, J. L. (1976). Receplormediated control of cholesterol metabolism. Science (Washington, D.C.) 191, 150-154.

Brown, M. S., Kovanen, P. T., AND Goldstein, J. L. (1981). Regulation of plasma cholesterol by lipoprotein receptors. Science (Washington, D.C.) 212, 628-635.

Busbee, D. L., Rankin, P. W., PAYNe, D. M., AND JASHEWAY, D. W. (1982). Binding of benzo[a]pyrene and intracellular transport of a bound electrophilic benzo $[a]$ pyrene metabolite by lipoproteins. Carcinogenesis 3, 1107-1112.

Carr, B. R., Parker, C. R., JR., MacDonald, P. C., AND SIMPSON, E. R. (1980). Metabolism of high density lipoprotein by human fetal adrenal tissue. Endocrinology 107, 1849-1854.

COUNSEll, R. E., Willette, R. E., AND DIGuilio, W. (1967). Tumor localizing agents. II. Radioiodinated analogs of 1,1-dichloro-2,2-bis(chlorophenyl)ethane. $J$. Med. Chem. 10, 975-977.

Faust, J. R., Goldstein, J. L., AND Brown, M. S. (1977). Receptor-mediated uptake of low density lipoprotein and utilization of its cholesterol for steroid synthesis in cultured mouse adrenal cells. J. Biol. Chem. 252, 4861-4871

Folch, J., Lees, M., and Sloane-Stanley, G. H. (1957). A simple method for the isolation and purifi- cation of total lipids from animal tissues. J. Biol Chem. 226, 497-509.

Gross, M. D.. Volk, T. W., Swanson, D. P., Thrall, J. H., GRekin, R. J., AND Beierwaltes, W. H. (1981). The role of pharmacologic manipulation in adrenal cortical scintigraphy. Semin. Nucl. Med. 11, $128-148$.

GWynNe, J. T., AND Hess, B. (1978). Binding and degradation of human ${ }^{125}$ I-HDL by rat adrenocortical cells. Metabolism 27, 1593-1600.

Havel, R. J., Eder, H. A., AND Bragdow, J. H. (1955). The distribution and chemical composition of ultracentrifugally separated lipoproteins in human serum. $J$. Clin. Invest. 34, 1345-1353.

Hobbelen, P. M. J., Coert, A., Geelen, J. A. A., AND VAN DFR VIES, J. (1975). Interactions of steroids with serum lipoproteins. Biochem. Pharmacol. 24, 165172.

Klausner, H. A., WilcoX, H. G., AND Dingell, J. V. (1975). The use of zonal ultracentrifugation in the investigation of the binding of $\Delta^{9}$-tetrahydrocannabinol by plasma lipoproteins. Drug. Metab. Dispos. 3, 314319.

KRAGH-HaNSEN, U. (1981). Molecular aspects of ligand binding to serum albumin. Pharmacol. Rev. 33, 17 53.

MaLiWal, B. P., AND GuTHRIE, F. E. (1981). Interaction of insecticides with human plasma lipoprotcins. Chem.Biol. Interact. 35, 177-188.

Marinovich, M., SiRTori, C. R., Holli, C. L., AND PAOLETTI, R. (1983). The binding of 2,3,7,8-tetrachlorodibenzodioxin to plasma lipoproteins may delay toxicity in experimental hyperlipidemia. Chem.-Biol. Interact. 45, 393-399.

Markwell, M. A. K., HaAs, S. M., Bieber, L. L., AND TOLBERT, N. E. (1978). A modification of the Lowry procedure to simplify protein determination in membrane and lipoprotein samples. Anal. Biochem. 87, 206-210.

NARAYAN, K. A. (1975). Electrophoretic methods for the separation of serum lipoproteins. In Analysis of Lipids and Lipoproteins (F. G. Perkins, ed.), pp. 225249. Amer. Oil Chem. Soc., Champaign, Ill.

Nordblom, G. D., Schappa, L. W., Floyd, E. E., LANGDON, R. B., AND Counsell, R. E. (1980). A comparison of cholesteryl oleate and 19-iodo-cholesteryl oleate as substrates for adrenal cholesterol esterase. $J$. Steroid Biochem. 13, 463-466.

Pittman, R. C., Carew, T. E., Attie, A. D., Witztum, J. L., Watanabe, Y., AND SteinberG, D. (1982). Recepior-dependent and receptor-independent degradation of low density lipoprotein in normal rabbits and in receptor-deficient mutant rabbits. J. Biol. Chem. 257, 7994-8000.

SEevers, R. H., AND Counsell, R. E. (1982). Radioio- 
dination techniques for small organic molecules. Chem. Rev. 82, 575-590.

SHIFF, T. S., RoHEIM, P. S., AND EDER, H. A. (1971). Effects of high sucrose diets and 4-aminopyrazolopyrimidine on serum lipids and lipoproteins in the rat. J. Lipid Res. 12, 596-603.

SHU, H. P., AND NiChOLS, A. V. (1979). Benzo[a]pyrene uptake by human plasma lipoproteins in vitro. Cancer Res. 39, 1224-1230.

ShU, H. P., AND Nichols, A. V. (1981). Uptake of lipophilic carcinogens by plasma lipoproteins: Structure-activity studies. Biochim. Biophys. Acta 665 , 376-384.

SkALSKY, H. L., AND GuthriE, F. E. (1978). Binding of insecticides to human serum proteins. Toxicol. Appl. Pharmacol. 43, 229-235.
Strauss, J. F., III, MacGregor, L. C., AND GWynne, J. T. (1982). Uptake of high density lipoproteins by rat ovaries in vivo and dispersed ovarian cells in vitro: Direct correlation of high density lipoprotein uptake with steroidogenic activity. J. Steroid Biochem. 6, 525-531.

Weinkom, R. J., Finn, A., Levin, V. A., AND Kane, J. P. (1980). Lipophilic drugs and lipoproteins: Partitioning effects on chloroethylnitrosourea reaction rates in serum. J. Pharmacol. Exp. Ther. 214, 318-323.

WEISGRABER, K. H., INNERARITY, T. L., AND MAHLEY, R. W. (1978). Role of the lysine residues of plasma lipoproteins in high affinity binding to cell surface receptors on human fibroblasts. J. Biol. Chem. 252, 9053-9062. 